\title{
Usaha dan Pengembangan Industri Kecil Berbasis Komunitas Lokal
}

\author{
Business and Development for Small Business Local Community-Based
}

\author{
Fachry Noviar Singka ${ }^{1^{*}}$, Nurmala K. Panjaitan ${ }^{2 \sharp}$ dan Tjahja Muhandri ${ }^{3 \sharp}$
}

\author{
${ }^{1}$ Program Magister Profesional Industri Kecil Menengah, Sekolah Pascasarjana Institut Pertanian Bogor \\ 2 Departemen Sains Komunikasi dan Pengembangan Masyarakat, Fakultas Ekologi Manusia Institut Pertanian Bogor \\ ${ }^{3}$ Departemen Ilmu dan Teknologi Pangan, Fakultas Teknologi Pertanian Institut Pertanian Bogor \\ \#Jl. Kamper Kampus IPB Darmaga, Bogor 16680
}

\begin{abstract}
ABSTRAK
Rumah Kreatif Balikpapan (RKB) merupakan industri kecil batik tulis dan kerajinan daur ulang yang sedang berkembang. Industri kecil ini melibatkan komunitas lokal yang terdiri dari para penyandang disabilitas dan ibu-ibu rumah tangga. Keberadaan RKB merupakan bentuk kontribusi perusahaan minyak dan gas bumi (migas) terhadap masyarakat daerah operasi melalui program pemberdayaan masyarakat yang biasa disebut Corporate Social Responsibility. Kondisi RKB yang masih berkembang memerlukan strategi pengembangan usaha yang terarah dan sistematis. Penelitian ini bertujuan mengkaji kondisi usaha, kinerja dan menyusun strategi pengembangan usaha RKBdalam upaya meningkatkan kemandirian dan keberlangsungan usaha. Pengumpulan data dilakukan melalui observasi, wawancara, focus group discussion dan penggunaan kuesioner kepada 30 responden yang dipilih secara sengaja yang menggunakan produk RKB. Data dianalisis secara deskriptif dan untuk kajian kinerja dianalisis dengan Importance Performance Analysis (IPA). Untuk kajian strategi, data diolah dengan matriks Internal Factor Evaluation (IFE), matriks External Factor Evaluation (EFE), matriks Internal External (IE), analisis matriks Strength, Weakness, Opportunities and Threats (SWOT) serta Quantitative Strategy Planning Matrix (QSPM). Hasil pemetaan kinerja dan kepentingan konsumen menggambarkan RKB perlu meningkatkan alokasi sumber daya memadai untuk peningkatan kinerja dalam hal harga produk, kecepatan pemesanan, ketelitian pekerja, penanganan keluhan dan media promosi. Berdasarkan analisis SWOT dan QSPM didapatkan prioritas strategis pengembangan utama yang diimplementasikan adalah restrukturisasi organisasi dan sistem manajemen, meningkatkan promosi, menjalin kerja sama dengan lembaga perbankan, menetapkan strategi harga pasar untuk menghadapi persaingan dan meningkatkan mutu layanan kepada pelanggan.
\end{abstract}

Kata kunci: industri kecil, komunitas lokal, pengembangan usaha

ABSTRACT

House of Balikpapan Creative (RKB) is a small and medium industry that has been developed and focuses on hand made batik and recycle handicraft. This small industry involves local community that consists of disability people and housewife. The existence of RKB is formed by oil and gas company contribution to local community in their operations area through Corporate Social Responsibility program. Current condition of RKB needs development strategy systematically. This research is aimed toreview the current state of business, to review the performance and to formalize the business development strategy of RKB in an attempt to increase the independence and sustainability of the business. Data collection was done through observation; interviewand focus group discussion as well as disseminating a questionnaire to 30 respondents, which used RKB products. The data is analyzed descriptively where as IPA analyzes performance review. Internal Factor Evaluation Matrix, External Factor Evaluation Matrix, Internal External Matrix, Strength, Weakness, Opportunities and Threats (SWOT) Matrix Analysis along with Quantitative Strategy Planning Matrix (QSPM) analyze strategy development. Outcome mapping performance and consumer interests described the RKB need to allocate

Korespondensi:

*) Jl. Raya Pajajaran, Kampus IPB Baranangsiang, Bogor; e-mail: fachry.singka @gmail.com 
adequate resources for improving the performance of the product in terms of price, speed orders, precision workers and handling complaints and media promotion. Based on the SWOT and QSPM analysis, the most major strategic priorities which need to be implemented are organizational restructuring and management system, increase promotion, partnering with banking institutions, sets the market price strategy to confront the competition, improve the quality of service to customers.

Key words: business development, local community, small industry

\section{PENDAHULUAN}

Dalam Rencana Strategis Kementrian Koperasi dan Usaha Mikro Kecil Menengah (UMKM) periode 2010-2014 dinyatakan bahwa pembangunan yang ditujukan kepada Koperasi dan UMKM diharapkan mampu menghantarkan penataan struktur pelaku ekonomi nasional lebih padu dan seimbang, baik dalam skala usaha, strata dan sektoral, sehingga berkembang struktur pelaku ekonomi nasional yang kokoh dan mandiri.

Dengan memperhatikan peran dan potensinya dalam perekonomian nasional, keberadaan Koperasi dan UMKM terbukti merupakan pelaku usaha yang mandiri, kukuh dan fleksibel, dalam kondisi normal maupun krisis sekalipun. Perkembangan UMKM pada tahun 2011-2012 disajikan pada Tabel 1.

Dari Tabel 1 dapat dilihat dua hal perkembangan UMKM saat ini, yakni jumlah unit usaha mengalami peningkatan 1.328.147 unit dari tahun sebelumnya, dengan pangsa rataan 99\%, artinya UMKM merupakan pelaku ekonomi yang dominan dan peningkatan jumlah tenaga kerja 5.935.051 orang dari tahun sebelumnya dengan pangsa rataan $97 \%$ yang menunjukkan UMKM mampu menyerap jumlah tenaga kerja, disadari bahwa dengan tingkat penyerapan tenaga kerja yang tinggi, sektor ini telah menjamin stabilitas pasar tenaga kerja, penekanan pengangguran dan menjadi wahana bangkitnya wirausaha baru, serta tumbuhnya wirausaha nasional yang tangguh dan mandiri.

Disisi lain, UMKM memiliki keterbatasan dalam berusaha seperti ketimpangan struktural dalam alokasi dan penguasaan sumber daya, ketidaktegasan keberpihakan negara pada implementasi pengembangan ekonomi rakyat dalam kebijakan dan pengembangan strategi industrialisasi, struktur pasar yang bersifat oligopolis, kinerja yang relatif terbatas pada hal yang klasikal (sumber daya manusia atau SDM), permodalan dan akses terhadap kelembagaan keuangan, manajemen, pemasaran dan informasi), terjadinya distorsi dan inkonsistensi kebijakan yang menyangkut upaya pengembangan (Hubeis, 2009).

Tabel 1. Perkembangan data usaha mikro, kecil, menengah dan usaha besar Tahun 2011-2012

\begin{tabular}{|c|c|c|c|c|c|c|c|c|}
\hline \multirow{2}{*}{ No } & \multirow{2}{*}{ Indikator } & \multirow{2}{*}{ Satuan } & \multicolumn{2}{|c|}{ Tahun $2011^{*}$ ) } & \multicolumn{2}{|c|}{ Tahun $2012^{* *}$ ) } & \multicolumn{2}{|c|}{$\begin{array}{l}\text { Perkembangan } \\
\text { tahun 2011-2012 }\end{array}$} \\
\hline & & & Jumlah & $\begin{array}{c}\text { Pangsa } \\
(\%)\end{array}$ & Jumlah & $\begin{array}{c}\text { Pangsa } \\
(\%)\end{array}$ & Jumlah & $(\%)$ \\
\hline$(1)$ & $(2)$ & $(3)$ & $(4)$ & $(5)$ & $(6)$ & $(7)$ & $(8)$ & $(9)$ \\
\hline \multirow[t]{7}{*}{1} & Unit Usaha $(\mathrm{A}+\mathrm{B})$ & (Unit) & 55.211 .396 & & 56.539 .560 & & 1.328.163 & 2,41 \\
\hline & a. Usaha Mikro, Kecil dan & & & & & & & \\
\hline & Menengah & (Unit) & 55.206 .444 & 99,99 & 56.534 .592 & 99,99 & 1.328.147 & 2,41 \\
\hline & - Usaha Mikro & (Unit) & 54.559 .969 & 98,82 & 55.856 .176 & 98,79 & 1.296 .207 & 2,38 \\
\hline & - Usaha Kecil & (Unit) & 602.195 & 1,09 & 629.418 & 1,11 & 27.223 & 4,52 \\
\hline & - Usaha Menengah & (Unit) & 44.280 & 0,08 & 48.997 & 0,09 & 4.717 & 10,65 \\
\hline & b. Usaha Besar & (Unit) & 4.952 & 0,01 & 4.968 & 0,01 & 16 & 0,32 \\
\hline \multirow[t]{6}{*}{2} & $\begin{array}{l}\text { Tenaga kerja Unit Usaha } \\
(\mathrm{A}+\mathrm{B})\end{array}$ & (Orang) & 104.613 .681 & & 110.808 .154 & & 6.194 .473 & 5,92 \\
\hline & $\begin{array}{l}\text { 1. Usaha Mikro, Kecil dan } \\
\text { Menengah }\end{array}$ & (Orang) & 101.722 .458 & 97,24 & 107.657 .509 & 97,16 & 5.935 .051 & 5,83 \\
\hline & - Usaha Mikro & (Orang) & 94.957 .797 & 90,77 & 99.859 .517 & 90,12 & 4.901 .720 & 5,16 \\
\hline & - Usaha Kecil & (Orang) & 3.919 .992 & 3,75 & 4.535 .970 & 4,09 & 615.977 & 15,71 \\
\hline & - Usaha Menengah & (Orang) & 2.844 .669 & 2,72 & 3.262 .023 & 2,94 & 417.354 & 14,67 \\
\hline & 2. Usaha Besar & (Orang) & 2.891 .224 & 2,76 & 3.150 .645 & 2,84 & 259.422 & 8,97 \\
\hline
\end{tabular}


Salah satu solusi dari keterbatasan UMKM dalam berusaha yaitu perlu ada pengembangan berbagai bentuk kerjasama dengan pihak-pihak perusahaan, diantaranya pengembangan kemitraan dan jaringan pasar bersama koperasi dan UMKM, tempat magang, alih teknologi, pendampingan dan advokasi, serta Corporate Social Responsibility atau CSR (Kementerian Koperasi dan UKM, 2013). Sesuai dengan Undang-undang PT No. 40 tahun 2007, pasal 74 (Republik Indonesia, 2007) yang menegaskan bahwa perseroan yang menjalankan kegiatan usahanya dibidang dan/atau berkaitan dengan sumber daya alam (SDA) wajib melaksanakan Tanggung jawab Sosial dan Lingkungan (TJSL). Berkaitan dengan pengembangan UMKM, TJSL ini diartikan perusahaan memberikan akses kepada masyarakat sekitar untuk berperan aktif dalam berwirausaha dan menjadikan program CSR sebagai bentuk kontribusi nyata dalam membantu pengembangan industri kecil menengah (IKM).

Rumah Kreatif Balikpapan (RKB) merupakan sebuah industri kecil dari komunitas usaha kecil dan ramah lingkungan di wilayah Kotamadya Balikpapan. RKB yang hadir sejak awal tahun 2013, beranggotakan penyandang disabilitas dan ibu-ibu Pembinaan Kesejahteraan Keluarga (PKK) di wilayah operasi perusahaan minyak dan gas bumi (migas). Kontribusi perusahaan migas ini sangat nyata dalam keberhasilan pengembangan RKB, dimulai dari bentuk pelatihan, penyertaan modal, sewa tempat dan pemasaran. Hal lain yang nyata menunjang keberhasilan program dalam peningkatan pendapatan adalah partisipasi aktif dari anggota komunitas. Penelitian Rosyida, Nasdian dan Tonny (2011), menemukan bahwa tingkat partisipasi anggota kelompok simpan pinjam di Desa Cihamerang dalam penyelenggaraan program pemberdayaan ekonomi lokal berhubungan dengan dampak sosial dan ekonomi masyarakat. Jika partisipasi anggota kelompok simpan pinjam dalam penyelenggaraan program tinggi, maka dampak sosial dan ekonomi akan tinggi. Jadi dampak sosial ekonomi yang diperoleh anggota kelompok simpan pinjam ditentukan oleh partisipasi dari stakeholder lain yang terkait.

Tujuan penelitian ini adalah (1) mengkaji kondisi usaha saat ini di UKM RKB, (2) mengkaji kinerja UKM RKB dan (3) menyusun strategi pengembangan usaha UKM RKB dalam upaya meningkatkan kemandirian dan keberlangsungan usaha.

\section{METODOLOGI}

Lokasi penelitian dilaksanakan di Workshop \& Gallery RKB, Jl. Wiluyo Puspoyudo No.1 Klandasan Ulu, Balikpapan, Provinsi Kalimantan Timur. Pemilihan lokasi ini dilakukan secara sengaja (purposive), dengan pertimbangan RKB merupakan salah satu program CSR perusahaan minyak dan gas bumi yang beroperasi di Kalimantan. Waktu kajian dilaksanakan dari bulan Oktober-Desember 2013.

Teknik pengumpulan data primer dilakukan dengan pengamatan langsung (observasi) di lapangan, wawancara dengan pengurus RKB, Focus Group Discussion (FGD) dengan anggota RKB danpengisian kuesioner. Data sekunder sebagai pelengkap data primer diperoleh melalui studi literatur, browsing internet dan memanfaatkan sumber-sumber literatur, serta referensi yang berkaitan dengan kajian ini.

Pengolahan dan analisis data meliputi:

1. Analisis kualitatif, dimana data yang telah terkumpul dideskripsikan atau digambarkan sebagaimana adanya. Hal ini bertujuan untuk mengkaji kondisi usaha RKB saat ini. Kasmir (2012) mengatakan prospek pengembangan bisnis dapat dilihat melalui beberapa aspek. Aspek-aspek ini tidak berdiri sendiri, akan tetapi saling berkaitan. Artinya jika salah satu aspek tidak dipenuhi, maka perlu dilakukan perbaikan atau tambahan yang diperlukan. Aspek-aspek yang dimaksud adalah aspek hukum, aspek pasar dan pemasaran, aspek keuangan, aspek teknis/operasi, aspek manajemen/organisasi, aspek ekonomi sosial dan aspek lingkungan.

2. Importance Perfomance Analysis (IPA) merupakan suatu model multi-atribut analisis. Teknik ini bertujuan mengkaji kinerja RKB dengan menampilkan informasi berkaitan faktor-faktor yang menurut konsumen sangat mempengaruhi kepuasaan dan loyalitas. Penerapan teknik IPA dimulai dengan identifikasi atribut-atribut yang relevan terhadap situasi pilihan yang diamati. Daftar atribut-atribut dapat dikembangkan dengan mengacu kepada literaturliteratur, melakukan interview, dan menggunakan penilaian manajerial (Rangkuti, 2006). Responden yang digunakan untuk mengkaji kinerja RKB adalah pengguna produk dengan jumlah 30 orang. Hasil perhitungan dengan IPA selanjutnya dimasukan dalam program software Statistical Package for the Social Science (SPSS) dalam bentuk diagram Kartesius untuk 
menentukan lokasi kuadran dari atributatribut yang ada.

3. Analisis SWOT dan QSPM merupakan alat analisis dalam menentukan formula strategik pengembangan usaha. Formula strategik disusun dengan menggabungkan berbagai indikator yang terdapat dalam kekuatan, kelemahan, peluang dan ancaman. Model penggabungannya dengan menggunakan matriks. Strategi yang dipilih adalah strategi yang dapat memecahkan isu strategik perusahaan (Rangkuti, 2013).

\section{HASIL DAN PEMBAHASAN}

Rumah Kreatif Balikpapan (RKB) merupakan sebuah produk kewirausahaan indusri kecil dari program pengembangan masyarakat atau Corporate Social Responsibility (CSR) perusahaan minyak dan gas yang beroperasi di Kalimantan Timur. Awalnya perusahaan migas ini menjalankan salah satu program CSR dalam bentuk pemberian kaki palsu kepada masyarakat penyandang disabilitas di sekitar wilayah operasinya, tepatnya di kota Balikpapan pada bulan Juli 2011. Kegiatan ini berlangsung sukses dan mendapatkan apresiasi baik dari pemerintah kota. Sejalan dengan pemberian kaki palsu, perusahaan, pemerintah dan penerima manfaat memandang perlu untuk kelanjutan program bagi para penyandang disabilitas ini dalam bentuk program kemandirian usaha. Harapannya para penyandang disabilitas memiliki kemampuan berusaha dan mampu berkontribusi pada pertumbuhan ekonomi kota, khususnya pengembangan IKM.

Awalnya program kemandirian usaha yang disepakati adalah kerajinan batik tulis. Serangkaian pelatihan batik tulis dilaksanakan secara berjenjang dengan harapan peserta lebih memahami secara teknis proses pembatikan dan memahami industri kecil batik tulis. Peserta pelatihan tidak hanya terdiri dari masyarakat penyandang disabilitas, namun dihadiri oleh ibuibu PKK di sekitar wilayah operasi Balikpapan. Keterlibatan ibu-ibu rumah tangga tersebut diharapkan mampu memberikan tambahan pendapatan untuk keluarganya. Secara informal perkumpulan batik tulis terbentuk pada tanggal 20 Desember 2011 di kantor Kelurahan Telaga Sari, Kota Balikpapan.

Dalam kurun waktu hampir satu tahun, para pembatik mulai banyak melakukan kegiatan produksi dan memandang perlu dibentuknya sebuah nama dari perkumpulannya. Nama yang muncul dari perkumpulan ini adalah Perkumpulan Komunitas Usaha Kecil Ramah Lingkungan "Mangrove" yang tercatat dalam Kantor Notaris Yuni Astuti, SH pada tanggal 4 Desember 2012 di Balikpapan. Perkumpulan ini secara sederhana disepakati dan dijalankan oleh pengurus (ketua, sekretaris dan bendahara). Berjalannya waktu, untuk meningkatkan ragam kerajinan industri kecil dan mengakomodasi lebih banyak lagi anggota komunitas, maka perkumpulan 'Mangrove' ini melalui pendanaan dari perusahaan migas membuat pelatihan kerajinan daur ulang dari sampah rumah tangga. Kedua bidang usaha yang saat ini dijalankan bernaung dalam wadah Rumah Kreatif Balikpapan dengan workshop dan gallery beralamatkan di Jl. Wiluyo Puspoyudo No.1, Klandasan Ulu, Balikpapan. Jumlah anggota yang melakukan kegiatan batik tulis 23 orang, sedangkan jumlah anggota yang melakukan kegiatan kerajinan daur ulang berjumlah 16 orang. Kepengurusan dalam organisasi belum memiliki aturan pembagian pekerjaan secara tertulis, baik dari sisi produksi dan pemasaran, bahkan secara informal kedua bidang usaha ini memiliki bendahara pada masing-masing bidang usaha.

Perusahaan yang dalam ini sebagai penyandang dana terbentuknya RKB masih melakukan pendampingan hingga saat ini, walaupun secara keorganisasian para pengrajin menjalankan usahanya tidak sepenuhnya tergantung dari pihak perusahaan. Kontribusi perusahaan disajikan pada Tabel 2. Pada Tabel 2 menunjukkan komitmen perusahaan terhadap pengembangan industri kecil RKB, utamanya dalam hal pelatihan guna meningkatan kemampuan komunitas dalam memproduksi. Investasi sosial ini merupakan kontribusi nyata untuk pengembangan usaha dan keberlangsungan usaha.

Kerajinan batik tulis RKB memfokuskan pada pengembangan batik tulis dengan menggunakan bahan pewarna alami dan motif khas Kalimantan. Produk yang dihasilkan berupa kain batik, selendang, hiasan dinding, kemeja, mukena, tas wanita, sarung bantal dan sajadah. Motif yang digunakan diambil dari inspirasi flora yang ada, yaitu tanaman pasak bumi, daun ulin, kantung semar, anggrek hitam Kalimantan dan paduan mangrove. Untuk motif flora diambil motif beruang madu dan penyu, serta motif lainnya seperti rig/anjungan minyak, pompa angguk dan lekuk Dayak. Sementara bidang usaha kerajinan daur ulang menggunakan bungkus-bungkus plastik dari sampah rumah tangga yang telah 
menghasilkan beragam produk, seperti asesoris, tas dan dompet. Harga jual dari produk-produk RKB disajikan pada Tabel 3.

Tabel 2. Kontribusi perusahan terhadap pengembangan RKB

\begin{tabular}{|c|c|c|}
\hline No. & Kontribusi & $\begin{array}{l}\text { Nilai Kontribusi } \\
\text { (Rp) }\end{array}$ \\
\hline & $\underline{\text { Usaha Batik Tulis }}$ & \\
\hline 1. & Pelatihan Batik Tingkat Dasar & 155.350 .000 \\
\hline 2. & $\begin{array}{l}\text { Pelatihan Batik Tingkat } \\
\text { Lanjutan }\end{array}$ & 135.225 .600 \\
\hline 3. & Pendampingan Teknis Batik & 9.389 .350 \\
\hline 4. & Pendampingan Teknis Batik & 4.123 .000 \\
\hline 5. & Perlengkapan Rumah Batik & 56.531 .500 \\
\hline 6. & Sewa dan renovasi RKB & 307.270 .400 \\
\hline \multirow[t]{3}{*}{7.} & Pameran & 14.729 .900 \\
\hline & Sub total & 682.619 .750 \\
\hline & $\underline{\text { Kerajinan Daur Ulang }}$ & \\
\hline 1. & $\begin{array}{l}\text { Pelatihan Pengelolaan } \\
\text { Limbah Plastik }\end{array}$ & 43.840 .000 \\
\hline 2. & $\begin{array}{l}\text { Pelatihan Tingkat Lanjut } \\
\text { Pembuatan Aneka Kerajinan }\end{array}$ & 82.008 .000 \\
\hline 3. & $\begin{array}{l}\text { Pelatihan Pembuatan Aneka } \\
\text { Bunga Berbahan Baku } \\
\text { Limbah }\end{array}$ & 27.449 .000 \\
\hline 4. & Peralatan & 6.869 .000 \\
\hline \multirow[t]{3}{*}{5.} & Bahan Baku & 4.499 .000 \\
\hline & Sub total & 164.665 .000 \\
\hline & Total & 847.284 .750 \\
\hline
\end{tabular}

Tabel 3. Harga jual produk-produk RKB

\begin{tabular}{lr}
\hline \multicolumn{1}{c}{ Jenis produk batik tulis } & Kisaran harga (Rp) \\
\hline Baju pria & $750.000-1.200 .000$ \\
Baju perempuan & $600.000-650.000$ \\
Kain batik tulis $(1.10 \times 2.30 \mathrm{~cm})$ & $600.000-900.000$ \\
Lukisan batik & $1.200 .000-2.500 .000$ \\
Sajadah & $350.000-400.000$ \\
Tas & $200.000-250.000$ \\
Selendang sutra & $400.000-450.000$ \\
Selendang santung & $150.000-200.000$ \\
Selendang katun & $250.000-300.000$ \\
\hline \multicolumn{1}{c}{ Jenis produk daur ulang } & Kisaran harga \\
\hline Dompet tangan & $75.000-100.000$ \\
Dompet dari tas kresek & $100.000-250.000$ \\
Tas & $100.000-200.000$ \\
Bunga & $50.000-100.000$ \\
Baju boneka & $75.000-100.000$ \\
Bros & $12.500-35.000$ \\
\hline
\end{tabular}

RKB menetapkan harga produk-produknya bervariasi, tergantung jenis produk, harga bahan baku dan biaya produksi. Besarnya harga jual ditentukan berdasarkan pada perhitungan seluruh biaya yang dikeluarkan unit usaha, walaupun belum dilakukan perhitungan dengan cermat.
Secara sederhana faktor-faktor penyusunan harga produk RKB berdasarkan seperti Tabel 4 .

Tabel 4. Faktor penyusun harga jual produk RKB

\begin{tabular}{lc}
\hline Faktor Penyusun & $\begin{array}{c}\text { Kontribusi Rataan } \\
(\%)\end{array}$ \\
\hline Biaya bahan baku & 30 \\
Biaya produksi & 20 \\
Biaya overhead & 20 \\
Target keuntungan & 30 \\
\hline Harga jual produk & 100 \\
\hline
\end{tabular}

Faktor-faktor yang dijadikan patokan oleh unit usaha dalam menetapkan harga jual adalah biaya bahan baku utama, biaya produksi, biaya overhead dan target keuntungan. Biaya bahan baku utama diperoleh dari total pemakaian seluruh bahan baku. Biaya operasi diperoleh dari upah tenaga kerja dan biaya tambahan lainnya. Biaya overhead terdiri atas biaya listrik dan air, serta biaya-biaya tak terduga RKB. Sementara RKB masih mematok dengan tingkat keuntungan 30\% untuk setiap produk yang dijual.

Dari sisi penjualan, produk RKB telah banyak digunakan oleh perusahaan migas yang beroperasi di Kalimantan Timur, pegawai pemerintahan Kota Balikpapan dan masyarakat umum yang mengetahui keberadaan produk RKB. Pembelian produk dilakukan melalui sistem pemesanan dan pembelian langsung di workshop RKB. Pihak RKB mendefinisikan, memilih dan mendesain suatu produk disesuaikan dengan kebutuhan dan keinginan konsumen dengan tetap menampilkan kekhasan dari material dan motif. Produk-produk RKB menggunakan nama Mangrove. Merek adalah suatu penawaran dari sumber yang diketahui. Merek menimbulkan banyak asosiasi dibenak orang yang membentuk merek tersebut. Semua perusahaan berjuang untuk membangun citra merek yang kuat, disukai dan unik (Kotler dan Keller, 2013).

Kegiatan promosi masih dilakukan secara sederhana melalui penyampaian dari mulut ke mulut antar pelanggan dan perusahaan, serta pembagian brosur di lokasi pameran. Komunitas RKB juga berpartisipasi dalam pameran-pameran yang disponsori oleh perusahaan, yaitu Balikpapan Expo, Bazaar Charity di Balikpapan, IPA Exhibition di Jakarta dan CraftIna di Jakarta yang didukung oleh Dinas Perindagkop Kota Balikpapan. Kegiatan humas dan publisitas dilakukan dengan membina hubungan baik dengan para pelanggan dan pengunjung, serta turut berpartisipasi dalam kegiatan pemerintah kota Balikpapan. 
Pemasaran hubungan (relationship marketing) bertujuan membangun hubungan jangka panjang yang saling memuaskan dengan konstituen kunci guna mendapatkan dan mempertahankan bisnis (Kotler dan Keller, 2013).

Pencatatan keuangan pada usaha RKB belum menerapkan sistem akuntansi yang baik. Hingga saat ini telah terjadi tiga kali pergantian bendahara tanpa ada serah terima laporan keuangan yang jelas. Catatan dalam laporan keuangan yang ada bersifat sangat sederhana dan tidak mencatat perkembangan keuangan dari awal produksi, sehingga tidak dapat digunakan untuk menganalisis perkembangan keuangan RKB. Data omset total produksi yang tersedia dari bulan Juni-Desember 2013 tercatat Rp77.488.500 (data diolah dari RKB 2013).

Selain itu, RKB belum memiliki pola manajemen yang baik. Sebagai contoh, RKB belum memiliki visi dan misi yang jelas dalam usaha yang sedang dijalankannya. Perhitungan dan penentuan tentang apa yang akan dikerjakan dan bagaimana tata cara yang harus dilakukan dalam rangka mencapai tujuan belum terencana dengan baik. Dalam pelaksanaan produksi beberapa hal masih terkendala, baik dari sisi komunikasi antar rekan kerja, kepemimpinan dalam menentukan produksi, pengarahan dan penjelasan mekanisme kerja, serta pendokumentasian material dan proses produksi.

\section{Kinerja Usaha Rumah Kreatif Balikpapan}

Penentuan kinerja usaha yang dilakukan RKB dianalisis melalui beragam atribut perhitungan rataan antara tingkat kinerja dan tingkat kepentingan konsumen. Kasmir (2012) mengatakan prospek pengembangan bisnis dapat dilihat melalui beberapa aspek dan aspek-aspek tersebut tidak berdiri sendiri akan tetapi saling berkaitan. Perbaikan dan penambahan dalam pengelolaan bisnis sangat dianjurkan, urutan penilaiannya berdasarkan pertimbangan prioritas, bahkan ada aspek yang seharusnya belum ditelaah lebih jauh karena tidak terlalu nyata dalam perkembangan UKM yang baru mulai dan sedang berkembang. Hasil identifikasi dan penilaian kinerja RKB disajikan pada Tabel 5.

Dari perhitungan Tabel 5, beberapa atribut yang paling nyata diperlukan adanya perbaikan adalah harga dengan nilai 1,67 , kemasan produk dengan nilai 1,67 , ketersediaan produk dengan nilai 1,50 , selanjutnya atribut-atribut dalam media promosi dan informasi masih dianggap rendah dibandingkan dengan kepentingan konsumen. Sementara itu, beragam corak yang dihasilkan dan atribut tempat RKB memiliki nilai kinerja yang nyata memenuhi kebutuhan konsumen.

Tabel 5. Perhitungan rataan dari penilaian tingkat kinerja dan tingkat kepentingan responden terhadap atribut produk dan jasa RKB

\begin{tabular}{|c|c|c|c|}
\hline Kode & Atribut & $\begin{array}{c}\text { Rataan } \\
\text { Kinerja } \\
(X)\end{array}$ & $\begin{array}{c}\text { Rataan } \\
\text { Kepen- } \\
\text { tingan (Y) }\end{array}$ \\
\hline \multicolumn{4}{|c|}{ Produk } \\
\hline 1 & Corak atau motif & 2,73 & 3,00 \\
\hline 2 & Warna produk & 2,43 & 3,00 \\
\hline 3 & Harga & 1,67 & 3,00 \\
\hline 4 & Variasi produk & 2,50 & 2,50 \\
\hline 5 & Kemasan produk & 1,67 & 2,67 \\
\hline 6 & Daya tahan & 2,00 & 2,83 \\
\hline 7 & Ketersediaan & 1,50 & 2,50 \\
\hline 8 & Merk & 2,00 & 2,33 \\
\hline \multicolumn{4}{|c|}{ Pelayanan Konsumen } \\
\hline 9 & $\begin{array}{l}\text { Kecepatan } \\
\text { pemesanan }\end{array}$ & 2,00 & 3,00 \\
\hline 10 & Keramahan pekerja & 2,67 & 3,00 \\
\hline 11 & Ketelitian pekerja & 2,00 & 2,83 \\
\hline 12 & Penanganan keluhan & 2.03 & 3,00 \\
\hline 13 & Waktu pelayanan & 2,16 & 2,53 \\
\hline \multicolumn{4}{|c|}{ Transaksi Penjualan } \\
\hline 14 & $\begin{array}{l}\text { Kecepatan pelayanan } \\
\text { kasir }\end{array}$ & 2,07 & 2,50 \\
\hline 15 & Bukti pembelian & 1,83 & 2,50 \\
\hline 16 & Ketelitian bertransaksi & 2,10 & 2,16 \\
\hline 17 & Kantong belanjaan & 1,67 & 2,60 \\
\hline 18 & Peralatan transaksi & 1,50 & 2,67 \\
\hline \multicolumn{4}{|c|}{ Tempat } \\
\hline 19 & Lokasi & 2,90 & 3,00 \\
\hline 20 & Lingkungan & 2,83 & 3,00 \\
\hline 21 & Ketersediaan parkir & 2,23 & 2,83 \\
\hline 22 & $\begin{array}{l}\text { Akses transportasi } \\
\text { umum }\end{array}$ & 2,86 & 2,83 \\
\hline 23 & Tata ruang show room & 2,80 & 2,67 \\
\hline 24 & Tata letak produk & 2,17 & 2,60 \\
\hline 25 & Fasilitas lain & 2,07 & 2,17 \\
\hline \multicolumn{4}{|c|}{ Media Promosi dan Informasi } \\
\hline 26 & Media promosi & 1,17 & 3,00 \\
\hline 27 & Kejelasan informasi & 1,17 & 3,00 \\
\hline 28 & $\begin{array}{l}\text { Ketersediaan } \\
\text { informasi }\end{array}$ & 1,17 & 3,00 \\
\hline 29 & Sebagai cindera mata & 2,03 & 2,90 \\
\hline 30 & Daya tarik pasar lokal & 2,17 & 3,00 \\
\hline 31 & $\begin{array}{l}\text { Daya tarik pasar } \\
\text { nasional }\end{array}$ & 1,80 & 2,67 \\
\hline \multirow{2}{*}{\multicolumn{2}{|c|}{$\begin{array}{c}\text { Rataan (berdasarkan jumlah } \\
\text { atribut) }\end{array}$}} & 63,09 & 85,29 \\
\hline & & 2,06 & 2,75 \\
\hline
\end{tabular}

Seiring dengan berjalannya waktu, setiap atribut produk dapat mempengaruhi kepuasan 
konsumen dan hal ini perlu diperbaiki. Perbaikan dan kinerja tersebut perlu mempertimbangkan sumber daya yang terbatas, sehingga perusahaan harus dapat mengalokasikan sumber daya terhadap perbaikan kinerja atribut yang mampu memberikan manfaat lebih besar untuk kepuasan konsumen. Hal-hal yang perlu dipertimbangkan oleh pihak RKB adalah memprioritaskan atribut yang dianggap memiliki tingkat kepentingan tinggi oleh konsumen, namun memiliki tingkat kinerja rendah. Salah satu cara untuk menentukan prioritas perbaikan terhadap kinerja atribut produk maupun jasa adalah menggunakan analisis kuadran Kartesius yang disajikan pada Gambar 1.

Secara umum, harga dan promosi bisa dikatakan hal yang perlu dibenahi oleh RKB. Produk RKB yang menjadi unggulan didominasi oleh produk batik tulis, karena corak, warna dan kekhasannya.

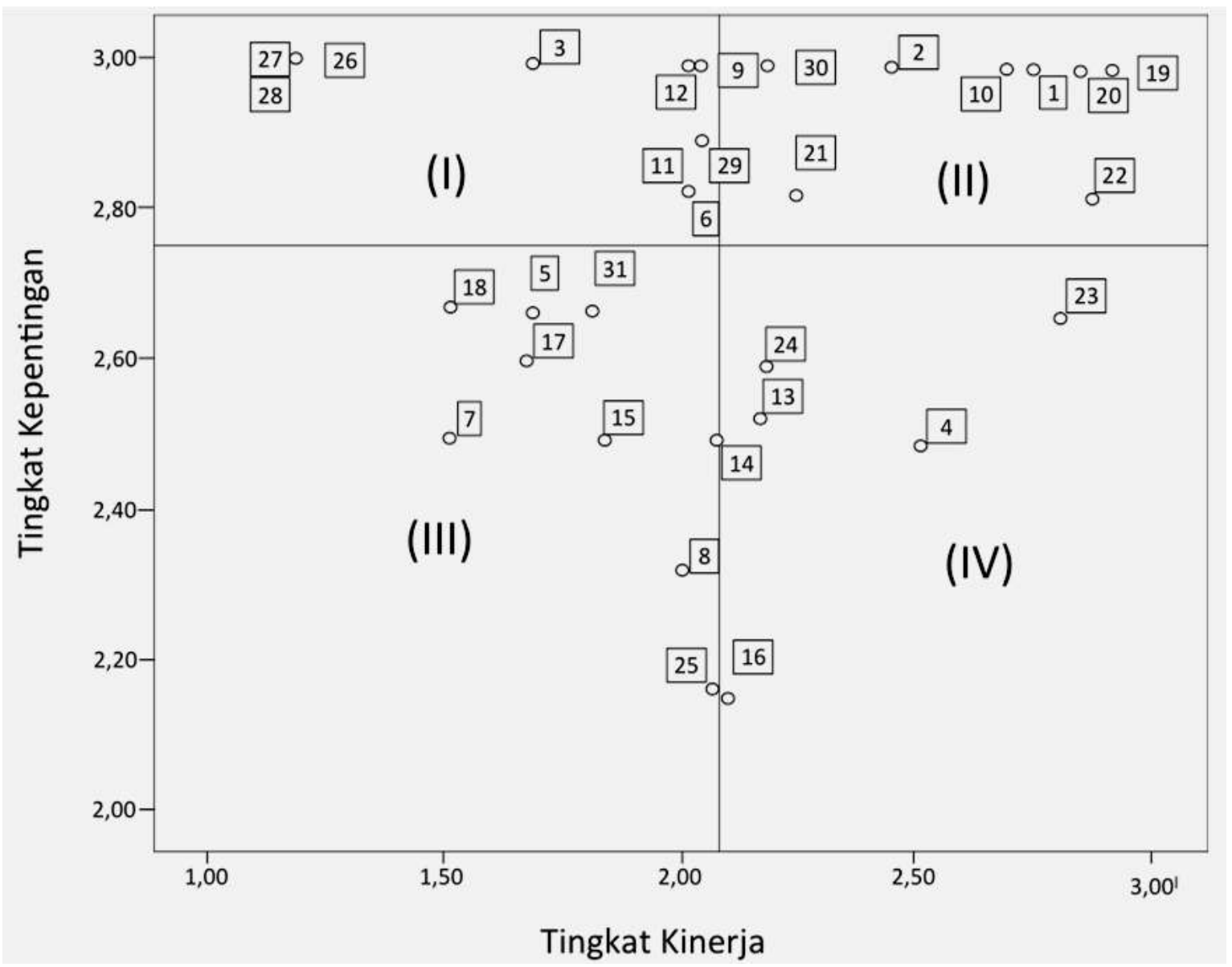

Gambar 1. Pembagian kuadran Kartesius RKB

Keterangan:

1. Pada kuadran I, faktor-faktor yang terletak pada kuadran ini dianggap sangat penting, sehingga pihak RKB perlu mengalokasikan sumber daya memadai untuk peningkatan kinerja. Faktor-faktor tersebut adalah harga yang relatif tinggi, kecepatan pemesanan, ketelitian pekerja, penanganan keluhan, media promosi, kejelasan informasi, ketersediaan informasi dan produk RKB sebagai cindera mata.

2. Pada kuadran II, faktor-faktor dianggap perlu untuk tetap dipertahankan sebagai penunjang kepuasan konsumen, sehingga pihak RKB berkewajiban mempertahankan prestasi yang ada. Faktor-faktor tersebut adalah corak dan motif, warna, keramahan pekerja, lokasi, lingkungan sekitar, parkir, akses dan daya tarik pasar lokal.

3. Pada kuadran III, faktor-faktor dianggap tidak terlalu penting atau prioritas rendah. Faktor-faktor tersebut adalah kemasan, ketersediaan, merk, kecepatan kasir, kantong belanja, peralatan transaksi, fasilitas lain dan daya tarik pasar nasional.

4. Pada kuadran IV, faktor-faktor dianggap tidak terlalu penting bagi konsumen, namun memiliki kinerja yang sangat baik. Faktor-faktor tersebut adalah tata ruang show room, waktu pelayanan, variasi produk dan pelayanan kasir. 


\section{Strategi Pengembangan Usaha}

Berdasarkan hasil wawancara dengan berbagai pihak di lingkungan RKB, perusahaan yang mendanai dan FGD dengan anggota $\mathrm{RKB}$, maka dapat diidentifikasi kondisi lingkungan internal berupa kekuatan (strengths) dan kelemahan (weaknesses) dan kondisi eksternal yang meliputi peluang (opportunities) dan ancaman (threats). Hasil identifikasi menggunakan matriks IFE dan EFE, dimana terdapat pembobotan dan pemberian rating dari faktor-faktor yang diidentifikasi, sebagaimana yang disajikan pada Tabel 6 dan 7 .

Berdasarkan nilai dari matriks IFE dan EFE pada Tabel 6 dan 7, terlihat komposisi nilai dari kekuatan, kelemahan, peluang dan ancaman RKB dengan nilai rataan IFE 2,571 dan nilai EFE 2,427. Selanjutnya jumlah nilai dari masing-masing tabel tersebut dimasukkan dalam matriks IE untuk mengetahui posisi usaha RKB (Gambar 2).
Dari hasil matriks IE pada Gambar 2, terlihat RKB berada pada kotak kuadran V, yaitu tumbuh dan stabil. Strategi yang disarankan pada kondisi tersebut adalah strategi penetrasi pasar (market penetration), pengembangan produk (product development) dan pengembangan pasar (market development). Witoko, Syarief dan Raharja (2013) mengatakan strategi penetrasi pasar adalah memberikan harga spesial bagi pelanggan yang membeli secara kontinu dan jumlah besar. Strategi pengembangan produk mengarah pada perbaikan mutu bahan baku dan strategi pengembangan pasar menambah konsumen baru. Selanjutnya dari analisis matriks IFE, EFE dan matriks IE dapat disusun analisis SWOT untuk merumuskan strategi pengembangan usaha. Perumusan strategi unit usaha RKB dengan matriks SWOT disajikan pada Gambar 3.

Tabel 6. Matriks IFE rumah kreatif Balikpapan

\begin{tabular}{lccc}
\hline \multicolumn{1}{c}{ Faktor-faktor internal kunci } & $\begin{array}{c}\text { Bobot } \\
(\mathrm{a})\end{array}$ & $\begin{array}{c}\text { Rating } \\
(\mathrm{b})\end{array}$ & $\begin{array}{c}\text { Nilai } \\
(\mathrm{a} \times \mathrm{b})\end{array}$ \\
\hline Kekuatan & & & \\
- Memiliki produk khas & 0,134 & 4 & 0,536 \\
- Memiliki SDM potensial untuk dikembangkan & 0,134 & 3 & 0,402 \\
- Memiliki sarana bekerja yang baik & 0,134 & 4 & 0,536 \\
- Mendapat dukungan dari perusahaan dan pemerintah & 0,143 & 4 & 0,571 \\
\hline Kelemahan & & & \\
- Belum ada kejelasan visi dan misi & 0,134 & 1 & 0,134 \\
- Kompetensi SDM yang lemah dalam pengorganisasian & 0,134 & 1 & 0,134 \\
$\quad$ dan pengelolaan keuangan & 0,116 & 1 & 0,116 \\
- Belum ada strategi pemasaran yang terencana & 0,071 & 2 & 0,143 \\
- Harga produk relatif mahal & 1 & & 2,571 \\
\hline Jumlah & & & \\
\hline
\end{tabular}

Tabel 7. Matriks EFE rumah kreatif Balikpapan

\begin{tabular}{lccc}
\hline \multicolumn{1}{c}{ Faktor-faktor eksternal kunci } & $\begin{array}{c}\text { Bobot } \\
(\mathrm{a})\end{array}$ & $\begin{array}{c}\text { Rating } \\
(\mathrm{b})\end{array}$ & $\begin{array}{c}\text { Nilai } \\
(\mathrm{a} \times \mathrm{x} \text { b })\end{array}$ \\
\hline Peluang & & 3 & 0,366 \\
- Segmentasi pasar luas & 0,122 & 3 & 0,366 \\
- Meningkatnya tren konsumen untuk produk ramah & 0,122 & & 0,488 \\
lingkungan & & 4 & 0,366 \\
- Perkembangan teknologi informasi (TI) & 0,122 & 3 & \\
- Batik sebagai pakaian nasional Indonesia & 0,122 & & 0,390 \\
Ancaman & & 2 & 0,268 \\
- Munculnya pesaing yang identik & 0,195 & 2 & 0,183 \\
- Situasi ekonomi dan politik dalam negeri tidak stabil & 0,134 & 1 & 2,427 \\
- Bantuan perusahaan yang mendanai dihentikan & 0,183 & 1 & \\
\hline Jumlah & & & \\
\hline
\end{tabular}




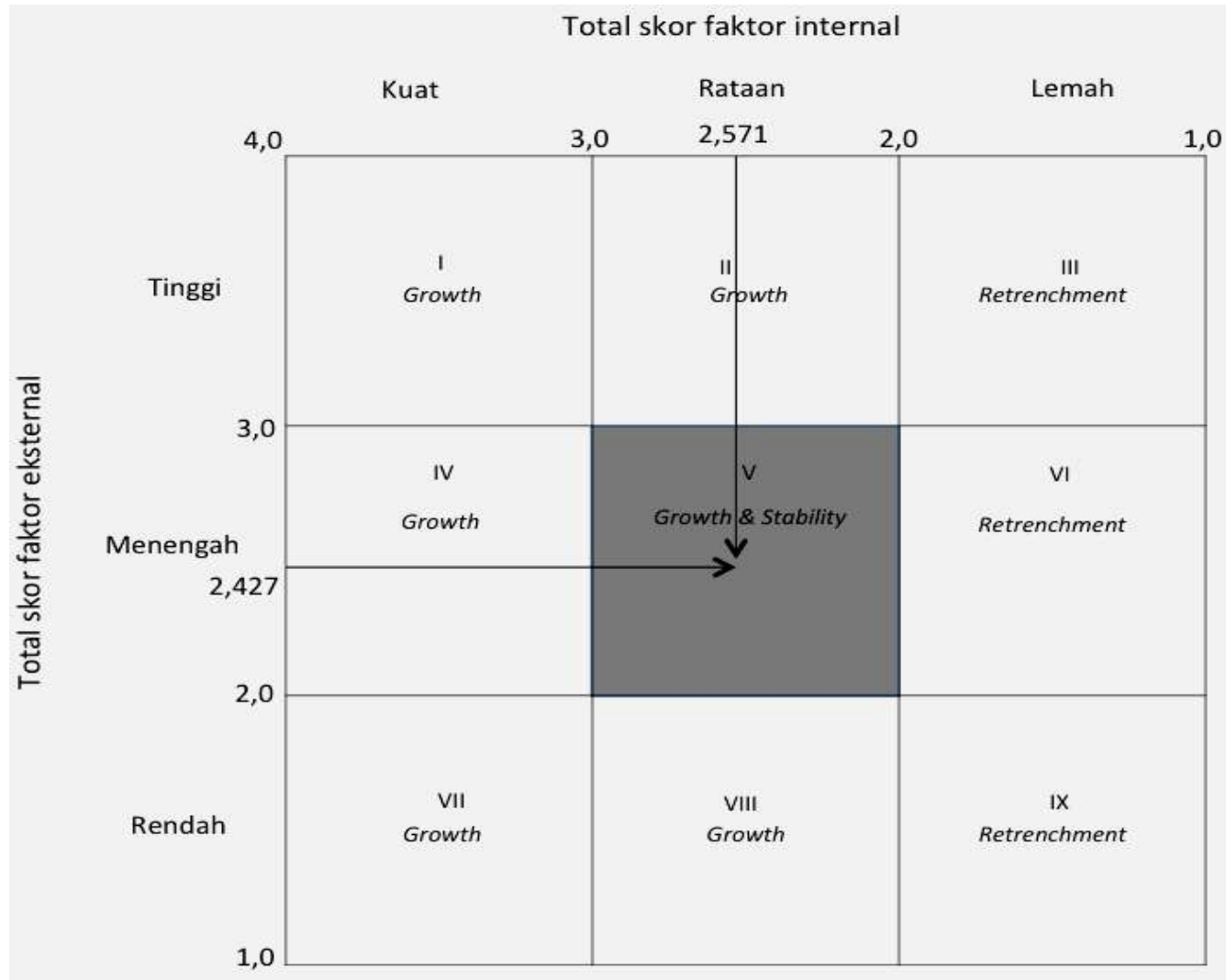

Gambar 2. Hasil matriks IE

\begin{tabular}{|c|c|c|}
\hline Faktor Eksternal & $\begin{array}{l}\text { Kekuatan (S) } \\
\text { 1. Memiliki produk khas } \\
\text { 2. Memiliki SDM potensial untuk } \\
\text { dikembangkan } \\
\text { 3. Memiliki sarana bekerja yang } \\
\text { baik } \\
\text { 4. Mendapat dukungan dari } \\
\text { perusahaan dan pemerintah }\end{array}$ & $\begin{array}{l}\text { Kelemahan }(\mathrm{W}) \\
\text { 1. Belum ada kejelasan visi dan misi } \\
\text { 2. Kompetensi SDM lemah dalam } \\
\text { pengorganisasian dan pengelolaan } \\
\text { keuangan } \\
\text { 3. Belum ada strategi pemasaran } \\
\text { yang terencana } \\
\text { 4. Harga produk relatif mahal }\end{array}$ \\
\hline $\begin{array}{l}\quad \text { Peluang }(\mathrm{O}) \\
\text { 1. Segmentasi pasar luas } \\
\text { 2. Meningkatnya tren } \\
\text { konsumen untuk produk } \\
\text { ramah lingkungan. } \\
\text { 3. Perkembangan TI } \\
\text { 4. Batik sebagai pakaian } \\
\text { nasional Indonesia }\end{array}$ & 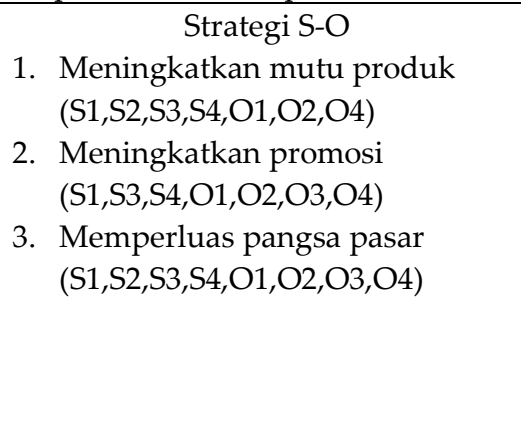 & $\begin{array}{l}\text { Strategi } \mathrm{W}-\mathrm{O} \\
\text { 1. } \\
\text { Restrukturisasi organisasi dan } \\
\text { sistem manajemen }(\mathrm{W} 1, \mathrm{~W} 2, \mathrm{~W} 3, \mathrm{~W} 4, \\
\mathrm{O} 1, \mathrm{O} 2) \\
\text { 2. } \\
\text { Meningkatkan kemampuan } \mathrm{SDM} \\
\text { (W2,W3,O2,O3) } \\
\text { 3. Mengembangkan program- } \\
\text { program efisiensi dan pengendali- } \\
\text { an biaya produksi } \\
\text { (W2,W4,O1,O2,O3,O4) }\end{array}$ \\
\hline $\begin{array}{l}\text { Ancaman }(\mathrm{T}) \\
\text { 1. Munculnya pesaing } \\
\text { identik } \\
\text { 2. Situasi ekonomi dan } \\
\text { politik dalam negeri tidak } \\
\text { stabil } \\
\text { 3. Bantuan perusahaan yang } \\
\text { mendanai dihentikan }\end{array}$ & $\begin{array}{l}\text { Strategi S-T } \\
\text { 1. Menetapkan strategi harga pasar } \\
\text { untuk menghadapi persaingan } \\
\text { (S1,T1) } \\
\text { 2. Meningkatkan mutu layanan } \\
\text { kepada pelanggan (S1,S3,S4, } \\
\mathrm{T} 1, \mathrm{~T} 2, \mathrm{~T} 3) \\
\text { 3. Menjalin kerjasama dengan } \\
\text { lembaga perbankan }(\mathrm{S} 4, \mathrm{~T} 3)\end{array}$ & \begin{tabular}{ll}
\multicolumn{1}{c}{ Strategi W-T } \\
1. & \multicolumn{1}{c}{ Meningkatkan teknologi } \\
$(\mathrm{W} 2, \mathrm{~W} 3, \mathrm{~W} 4, \mathrm{~T} 1, \mathrm{~T} 2)$ \\
2.
\end{tabular} \\
\hline
\end{tabular}

Gambar 3. Matriks SWOT Rumah Kreatif Balikpapan 
Setelah diperoleh beberapa alternatif strategi dari analisis SWOT yang disajikan pada Tabel 8, selanjutnya menggunakan analisis QSPM untuk pemilihan alternatif strategi yang paling menarik diimplementasikan. Seluruh alternatif yang dihasilkan dirumuskan berdasarkan peringkatnya disajikan pada Tabel 8 .

Berdasarkan hasil analisis QSPM pada Tabel 9, dapat dilihat strategi terbaik yang dapat dilakukan saat ini adalah restrukturisasi organisasi dan sistem manajemen. Strategi ini dilakukan sebagai upaya untuk membenahi internal RKB agar nantinya memiliki aturan organisasi jelas dan terarah menghadapi persaingan dunia usaha yang semakin kompetitif, dengan nilai Total Attractiveness Score (TAS) tertinggi $(7,488)$.

Implikasi manajerial yang dapat digunakan oleh RKB dari empat strategi yang paling menarik berdasarkan hasil penelitian adalah:

1. Restrukturisasi organisasi dan sistem manajemen

Layaknya sebuah organisasi yang dinamis, saatnya RKB harus menentukan bentuk organisasi berorientasi bisnis untuk kesejahteraan pengrajinnya. Koperasi dinilai baik, karena dapat mengakomodir kepentingan anggotanya dan merupakan badan hukum yang didukung oleh pemerintah melalui UU No. 17 Tahun 2012 tentang Perkoperasian, Pasal 4 (Republik Indonesia, 2014). Keberadaan lembaga yang baik akan memperhatikan sistem dan prosedur keorganisasian, penciptaan produk, manajemen keuangan, pemasaran dan tentunya kesejahteraan anggotanya. Kelembagaan yang baik akan melakukan monitoring dan evaluasi (monev) secara reguler, sehingga peningkatan usaha lebih cepat dicapai melalui manajemen dalam suatu lembaga, maka RKB akan memiliki visi dan misi jelas, serta perencanaan usaha dalam jangka pendek dan jangka panjang, demi terwujudnya kemandirian usaha.

2. Meningkatkan promosi

Strategi yang dapat dijalankan untuk lebih meningkatkan kegiatan promosi adalah:

a. Advertorial. Advertorial dapat dijalankan dengan memasang halaman advertorial di surat kabar lokal, ataupun brosur berisi paparan logis dan menarik tentang alasan yang menguatkan mengapa produk RKB layak untuk dipertimbangkan dan dikonsumsi. Kemasan dan isi/materi dibuat semenarik mungkin, agar para pembaca dapat terpengaruh tanpa merasa ditipu oleh pembuat advertorial.

b. Testimoni. Testimoni dapat dilakukan di RKB untuk memperoleh "pengakuan" dari konsumen yang datang, untuk meyakinkan tentang uraian dari pihak perusahaan tentang mutu dari produk RKB.

c. Sales Force. Sales force diperlukan karena tidak semua orang pernah datang ke RKB, sehingga kehadiran sales force di ruang publik (mal, pusat pertokoan, perkantor-an dan lainnya) menjadi strategi untuk memasarkan produk secara agresif pada konsumen.

Tabel 8. Urutan prioritas strategi dari QSPM RKB

\begin{tabular}{llc}
\hline \multicolumn{1}{c}{ Alternatif Strategi } & $\begin{array}{c}\text { Total nilai daya } \\
\text { tarik }\end{array}$ & $\begin{array}{c}\text { Urutan } \\
\text { prioritas }\end{array}$ \\
\hline - Restrukturisasi organisasi dan sistem manajemen & 7,49 & $\mathrm{I}$ \\
- Meningkatkan promosi & 6,71 & $\mathrm{II}$ \\
- Menjalin kerjasama dengan lembaga perbankan & 6,69 & $\mathrm{III}$ \\
- Menetapkan strategi harga pasar untuk menghadapi & 6,65 & $\mathrm{IV}$ \\
- persaingan & & $\mathrm{V}$ \\
- Meningkatkan mutu layanan kepada pelanggan & 6,47 & $\mathrm{VI}$ \\
- Memperluas pangsa pasar & 6,45 & $\mathrm{VII}$ \\
- Meningkatkan teknologi & 6,38 & $\mathrm{VIII}$ \\
- Meningkatkan mutu produk & 6,18 & $\mathrm{IX}$ \\
- Meningkatkan kemampuan SDM & 6,06 & $\mathrm{X}$ \\
- Mengembangkan program-program efisiensi dan & 6,05 & $\mathrm{XI}$ \\
\hline
\end{tabular}


d. Media online. Saat ini, maraknya publikasi produk pada sosial media telah menunjukkan tingkat penjualan yang nyata, maka RKB seharusnya menggunakan fasilitas seperti website atau jejaring sosial untuk meraih pangsa pasar online.

3. Menjalin kerja sama dengan lembaga perbankan

Ketergantungan dengan perusahaan yang mendanai sudah saatnya dilepas dengan menciptakan rencana exit strategy dan melakukan kerja sama dengan pihak perbankan. Usaha yang sudah bankable akan memudahkan transaksi bisnis dan peminjaman modal di masa mendatang. Maraknya program pemerintah untuk program kemandirian usaha yang didukung oleh perbankan merupakan peluang, baik untuk RKB terbebas dari ketergantungan perusahaan.

4. Menetapkan strategi harga pasar untuk menghadapi persaingan

Harga produk RKB yang ditawarkan dinilai lebih mahal oleh hampir seluruh konsumen, apalagi untuk sebuah industri kecil yang belum dikenal luas. Alternatif strategi yang dapat dilakukan adalah menghitung ulang biaya produksi yang sesungguhnya agar diperoleh harga yang lebih terjangkau dan meningkatkan jumlah pembelian. Alternatif lain adalah tetap memberikan ekstra atau tambahan produk untuk transaksi pembelian dalam jumlah tertentu. Pihak RKB dapat memberlakukan diversifikasi harga untuk menjaring konsumen dari berbagai kalangan, tidak hanya konsumen dari kalangan ekonomi menengah ke atas, misalnya meluncurkan produk-produk khusus pelajar. Selain itu, indikator lain, seperti potongan harga dan bonus pembelian harus lebih diperhatikan oleh pihak unit usaha. Alternatif strategi yang dapat dilakukan adalah melaksanakan potongan harga secara teratur dan potongan harga hendaknya dilaksanakan pada momen yang tepat dan spesial, misalnya saat peluncuran produk baru atau pada bulan-bulan penting, seperti hari-hari besar keagamaan dan tahun kalendar siswa baru. Pemberian potongan harga tersebut diharapkan dapat memberikan kesan khusus bagi konsumen dan menjadi sesuatu hal yang ditunggutunggu, namun hendaknya perusahaan memperhitungkan dengan teliti agar pemberian potongan harga tersebut tidak berpotensi terhadap penurunan laba perusahaan.

\section{KESIMPULAN}

1. Kondisi usaha RKB yang berbasiskan komunitas lokal cukup berkembang, yaitu produk batik tulis dan kerajinan daur ulang RKB berorientasi ramah lingkungan mulai diakui oleh sebagian masyarakat Balikpapan dan para pendatang. Dukungan perusahaan yang mendanai dan pemerintah setempat sangat nyata dalam proses perkembangan usaha.

2. Berdasarkan hasil perhitungan IPA dan pemetaan kinerja dan kepentingan dalam diagram Kartesius, terdapat faktor-faktor yang dianggap perlu ditingkatkan, sehingga pihak RKB perlu mengalokasikan sumber daya memadai untuk peningkatan kinerja. Faktor-faktor tersebut adalah harga produk relatif tinggi, kecepatan pemesanan, ketelitian pekerja, penanganan keluhan, media promosi, ketersediaan informasi dan produk sebagai cindera mata. Sebaliknya untuk faktor-faktor yang dianggap sudah baik adalah corak dan motif utamanya produk batik tulis, warna, keramahan pekerja, lokasi strategik dan daya tarik pasar lokal.

3. Berdasarkan analisis matriks IE diketahui posisi RKB dalam kuadran V (tumbuh dan stabil), yaitu terdapat prospek yang baik bagi perkembangan usaha kecil RKB, diantaranya melakukan alternatif strategi produk, harga, tempat, dan promosi, baik dalam jangka pendek maupun jangka panjang, serta perbaikan kelembagaan secara internal. Selanjutnya dari hasil analisis matrik SWOT terdapat beberapa strategi alternatif untuk pengembangan usaha RKB dan dari QSPM diperoleh empat strategi yang paling utama untuk diimplementasikan adalah restrukturisasi organisasi dan sistem manajemen, meningkatkan promosi, menjalin kerjasama dengan lembaga perbankan dan menetapkan strategi harga pasar untuk menghadapi persaingan.

\section{DAFTAR PUSTAKA}

Hubeis, M. 2009. Prospek Usaha Kecil Dalam Wadah Inkubator Bisnis (Cetakan ke 2). Penerbit Ghalia Indonesia, Bogor.

Kasmir, J. 2012. Studi Kelayakan Bisnis (Cetakan ke-8). Penerbit Prenada Media Group, Jakarta.

Kementrian Koperasi dan UKM. 2013. Revitalisasi Peran Pendamping KUMKM. 
http://vertigopublish.com/assets/content/uk mindonesia/09 Majalah UKM Indonesia Network Juni-Juli 2013.pdf. (14 Mei 2014). Kotler, P., dan K.L. Keller. 2013. Manajemen Pemasaran (Edisi ke-13, Terjemahan). Penerbit Erlangga, Jakarta.

Rangkuti, F. 2013. SWOT Balanced ScorecardTeknik Menyusun Strategi Korporat yang Efektif plus Cara Mengelola Kinerja dan Risiko, (Cetakan ke-5). Penerbit Gramedia Pustaka Utama, Jakarta. .2006. Measuring Customer Satisfaction. PT Gramedia Pustaka Utama, Jakarta.

Rosyida, I. dan F. T. Nasdian. 2011. Partisipasi Masyarakat dan Stakeholder dalam Penyelenggaraan Program CSR dan Dampaknya terhadap Komunitas Perdesaan. Jurnal Sodality, 5(1): 51-70.
Republik Indonesia. 2007. Undang Undang Republik Indonesia No. 40 Tahun 2007 tentang Perseroan Terbatas. Lembaran Negara RI Tahun 2007, No. 106. Sekretariat Negara, Jakarta.

Republik Indonesia. 2012. Undang Undang Republik Indonesia No. 17 Tahun 2012 tentang Perkoperasian. Lembaran Negara RI Tahun 2012, No. 212. Sekretariat Negara, Jakarta

Wibhawa, B. 2011. Social Entrepreneurship Social Enterprise and Corporate Social Responsibility. Penerbit Widya Padjajaran, Bandung.

Witoko, P., R. Syarief dan S. Raharja. 2013. Kelayakan Strategi Pengembangan Usaha Pembenihan Ikan Patin di CV Mika Distrindo. Manajemen IKM, 8(2): 115-122. 